\title{
Motives of Masters for the Teaching Profession: Development of the MMTP Questionnaire
}

\author{
Wil Meeus, Marlies Baeten, and Liesje Coertjens \\ Faculty of Social Sciences, University of Antwerp, Venusstraat 35, 2000 Antwerpen, Belgium \\ Correspondence should be addressed to Wil Meeus; wil.meeus@uantwerpen.be
}

Received 12 May 2015; Accepted 1 July 2015

Academic Editor: Jose C. Nunez

Copyright (C) 2015 Wil Meeus et al. This is an open access article distributed under the Creative Commons Attribution License, which permits unrestricted use, distribution, and reproduction in any medium, provided the original work is properly cited.

\begin{abstract}
Increasing teacher shortages provide incentives for conducting research into the motives of future teachers aspiring to work in education. The present study builds on previous research into motivation for entering the teaching profession. Given the shortage of studies carried out with direct empirical foundations, multiphase factor analyses, and large respondent groups, the present research focuses on developing the questionnaire Motives of Masters for the Teaching Profession (MMTP) while meeting these methodological criteria. Master's students $(N=1200)$ described their motivations for entering the teaching profession. Confirmatory factor analysis $(N=707)$ was carried out in order to confirm the factor structure produced by the exploratory factor analysis $(N=145)$. On the basis of content and statistical arguments, a 7-factor solution was obtained and a 35-item questionnaire was produced. Future cross-contextual research on the MMTP should attempt to improve the generalizability of the questionnaire.
\end{abstract}

\section{Introduction}

Increasing teacher shortages mean that conducting research into the motives of future teachers aspiring to work in education is in the interests of a range of actors in different contexts [1]. Gaining insight into motivation for entering the teaching profession would provide valuable input for attracting more teachers to the profession and for preventing teachers from leaving the profession [2]. Teacher education could play an important role in this process by assessing the correspondence between students' motivation and the working reality and by offering support in the event of practice shock $[3,4]$. Research on future teachers' motivation may therefore help prevent burnout and loss of commitment [5-7].

Teacher education, and especially encounters with educational practice during experiences in the field, may have a significant influence on the motivation of future teachers. This motivation is likely to evolve in one of three directions [8]:

(i) from low to high motivation;

(ii) from high non-education-specific motivation to high education-specific motivation; (iii) from high to low motivation.

Factors that prove decisive in changing motivation include the development of a sense of professional competence and socioprofessional relationships with pupils, fellow students, teacher educators, and mentors.

Numerous studies have already been conducted on the nature of motivation. Common theoretical frameworks are based on three factors: intrinsic, altruistic, and extrinsic motivation, the first two of which are considered positive and the third negative [9-11]. Learning and development opportunities are related to intrinsic motivation, social involvement is related to altruistic motivation, and job security is related to extrinsic motivation. More recent research has used other theoretical frameworks such as the distinction between adaptive and maladaptive motivation, where adaptive motivation refers to a deep commitment to education [12]. The difference between this latter framework and the previous tripartite model is that it views certain extrinsic motives, such as ambition and as adaptive and therefore positive. Contemporary studies present more complex models that draw upon statistics to distinguish between factors and their positive or negative relation to teacher retention and wellbeing. 
The literature offers multiple studies in diverse contexts, using different methodology and leading to various outcomes. Table 1 provides a chronological overview of the most important studies from the last 20 years.

All studies cited attempt to construct models to identify categories of motivation for entering the teaching profession. The studies make use of different methods and techniques for scale construction. Scales were constructed on the basis of theories, previous studies, and surveys or on the basis of interviews with experts, teachers, and students. The proposed amount of factors range from 3 to 21 . Three out of ten studies rely solely on qualitative data. Samples used for quantitative analysis range from 74 to 1444 students.

The advantage of starting from theory is consistency, but this methodology offers no guarantee that empirical aspects are covered sufficiently. Similarly, making use of previous studies or surveys can prevent unnecessary repetition of investment, but the limitations of these previous studies will also be transferred to the new study. Conducting interviews with experts or in-service teachers obviously provides useful perspectives, but the data may be biased by the indirect way in which starters' motives are mapped. An empirical approach can overcome the weaknesses of the other methods and techniques mentioned because of its immediate relationship to reality. It is striking, however, that only studies 1 [10] and 5 [9] depart from a direct empirical investigation of the target group.

The scales used in the studies mentioned above vary widely, perhaps as a result of their methodological differences. First of all, the items differ in terms of both content and number. Significant differences were also found in terms of the thoroughness of the data analysis. The present research considers a two-phase factor analysis and a large respondent group $(N>500)$ as the minimum indications of thoroughness. Studies 1 [10], 2 [11], and 4 [13] make no use of factor analysis and only studies 7 [12] and 8 [14] use both confirmatory and explorative factor analysis. Moreover, most studies were based on small groups of respondents, with the exception of studies 5 [9], 8 [14], and 9 [15].

In summary, no recent study includes all of the three criteria outlined above, namely, a direct empirical foundation, a multiphase factor analysis, and a large respondent group. Studies 5 [9] and 8 [14] meet two of the three criteria, however. Study 5 [9] pays much attention to the empirical foundation within the context of teacher education in Jamaica and relies on a large respondent group for the exploratory factor analysis. Study 8 [14] conducts a thorough factor analysis but lacks a direct empirical foundation. Study 9 [15] confirms the shortcoming of study 8 [14] by adding empirical items (retrospectively) to the FIT-Choice scale used. The present research seeks to address these shortcomings in the literature by combining the three robust criteria mentioned above while mapping the motives of masters for the teaching profession.

\section{Objectives of the Research}

Our questionnaire was designed to map the motives of future teachers who start a one-year teacher education programme at a university in Flanders, Belgium. These students can only obtain a teaching certificate after obtaining a master's degree and apply to begin teacher education at the end of their master's programme. They are typically at least four years older than students who begin teacher education in their first year of higher education. These student teachers are highly educated and usually go on to teach in the upper years of secondary education or in higher education. Moreover, it is clear that this student group favours an academic teacher education: the same qualification can be obtained in Flanders by taking a nonacademic programme, but these students enrol on a university-taught course.

The position of teachers with a master's degree in the Flemish educational system has been the subject of debate for many years, a debate that was recently given new impetus by the discussion surrounding the reform of secondary education [16]. The aim is to attract more master's graduates into education, though it is unclear how this should be done. In addition, (a) there is also a shortage of teachers in secondary education, particularly for subjects such as mathematics, computer science, and natural science; (b) $30 \%$ of new teachers leave the profession within five years; and (c) teachers from the baby boom generation are now approaching retirement [17].

The aim of this study was to develop a questionnaire, the Motives of Masters for the Teaching Profession (MMTP), according to a robust methodology based on the three criteria we used to assess existing studies: an empirical foundation, multiphase factor analysis, and large respondent group. We restricted the study to a well-defined target group in a specific context, as explained above: students enrolled in Flemish academic teacher education. The research question we aimed to answer is as follows: What motives do future teachers in Flemish academic teacher education have for entering the teaching profession?

\section{Method}

3.1. Phase 1. Between 2004 and 2011, master's students taking teacher education programmes at two Flemish universities were asked to describe their motivations for entering the teaching profession. Five cohorts of student teachers were questioned at each university. Each cohort included between 100 and 200 student teachers. In total, approximately 1200 student teachers were included in the sample.

First, each student teacher was asked to list his or her personal motives for becoming a teacher. An inventory of these personal motives was then made per cohort and presented to all student teachers of that cohort. The inventory was publicly discussed for completion or adaptation. All inventories were subsequently integrated into one global inventory. After deleting doubles, the global inventory consisted of 148 items. These items were divided into nine provisional categories to facilitate the work of the experts. Then this global inventory was screened by a group of five experts (teacher educators working at universities), who collectively checked that the items were relevant (are all items related to motivation for teaching?), unique (are all items distinct from all others?), universal (are all items understandable in all contexts?), and clearly formulated (are all items open to one interpretation only?). 
TABLE 1: Overview of studies on measurement of motivation for entering the teaching profession.

\begin{tabular}{lllll}
\hline Scale & Scale construction & Quantitative factor analysis & Factors \\
\hline $\begin{array}{l}\text { Trainees' reasons for } \\
\text { choosing teaching as } \\
\text { their career [10] }\end{array}$ & $\begin{array}{l}\text { Open-ended questions }(N= \\
133 \text { students) }\end{array}$ & $\begin{array}{l}\text { None } \\
\text { 3-factor model based on } \\
\text { theoretical framework }\end{array}$ & $\begin{array}{l}\text { (1) Extrinsic } \\
\text { (2) Intrinsic } \\
\text { (3) Altruistic }\end{array}$ \\
\hline $\begin{array}{l}\text { Reasons for entry into } \\
\text { teaching [11] }\end{array}$ & $\begin{array}{l}\text { Existing questionnaire [18], } \\
\text { adapted after focus group }\end{array}$ & $\begin{array}{l}\text { None } \\
\text { 4-factor model based on a } \\
\text { posteriori categorization } \\
(N=272 \text { students) }\end{array}$ & $\begin{array}{l}\text { (1) Altruistic } \\
\text { (2) Nature of teaching job } \\
\text { (3) Job market } \\
\text { (4) Monetary and incentives }\end{array}$ \\
\hline $\begin{array}{l}\text { Students' selection of } \\
\text { the elementary } \\
\text { education major [19] }\end{array}$ & $\begin{array}{l}\text { By the researchers on the } \\
\text { basis of theory }\end{array}$ & $\begin{array}{l}\text { 6-factor model }(N=176 \\
\text { students) }\end{array}$ & $\begin{array}{l}\text { (1) Internal motives } \\
\text { (3) Status of the profession } \\
\text { (4) Relatives influences } \\
\text { (5) External motives } \\
\text { (6) Teacher influences }\end{array}$ \\
\hline
\end{tabular}

\begin{tabular}{|c|c|c|}
\hline 4 & $\begin{array}{l}\text { Student teachers' } \\
\text { motivation to become } \\
\text { a secondary school }\end{array}$ & $\begin{array}{l}\text { Previous studies, amended } \\
\text { by own explorative research }\end{array}$ \\
\hline
\end{tabular}

\begin{tabular}{|c|c|c|c|c|}
\hline 5 & $\begin{array}{l}\text { Reasons for choosing } \\
\text { the teaching } \\
\text { profession [9] }\end{array}$ & $\begin{array}{l}\text { Open interviews ( } N=96 \\
\text { students and } 4 \text { lecturers), } \\
\text { combined with focus groups } \\
(N=30 \text { students })\end{array}$ & $\begin{array}{l}\text { 3-factor model ( } N=1444 \\
\text { students) }\end{array}$ & $\begin{array}{l}\text { (1) Extrinsic } \\
\text { (2) Intrinsic } \\
\text { (3) Altruistic }\end{array}$ \\
\hline 6 & $\begin{array}{l}\text { Reasons for } \\
\text { respondents' choice of } \\
\text { teaching }[20]\end{array}$ & Brainstorm by experts & $\begin{array}{l}\begin{array}{l}5 \text {-factor model }(N=74 \\
\text { students })\end{array}\end{array}$ & $\begin{array}{l}\text { (1) Social status } \\
\text { (2) Career fit } \\
\text { (3) Prior considerations } \\
\text { (4) Financial reward } \\
\text { (5) Time for family }\end{array}$ \\
\hline 7 & $\begin{array}{l}\text { Modified } \\
\text { Orientations for } \\
\text { Teaching Survey } \\
\text { (MOTS) [12] }\end{array}$ & $\begin{array}{l}\text { Orientations for teaching } \\
\text { survey [21] }\end{array}$ & $\begin{array}{l}10 \text {-factor model }(N=98 \\
\text { students })\end{array}$ & $\begin{array}{l}\text { (1) Working with children } \\
\text { (2) Worth of teaching } \\
\text { (3) Intellectual stimulation } \\
\text { (4) Ease of entry/work } \\
\text { (5) Dissatisfaction } \\
\text { (6) Career considerations } \\
\text { (7) Help others } \\
\text { (8) Conditions } \\
\text { (9) Influence of others } \\
\text { (10) Pattern of interaction }\end{array}$ \\
\hline 8 & $\begin{array}{l}\text { Factors Influencing } \\
\text { Teaching Choice } \\
\text { (FIT-Choice) scale } \\
{[14]}\end{array}$ & $\begin{array}{l}\text { By the researchers on the } \\
\text { basis of theory and previous } \\
\text { studies }\end{array}$ & $\begin{array}{l}18 \text {-factor model } \\
(N=488+652)\end{array}$ & $\begin{array}{l}\text { (1) Intrinsic value } \\
\text { (2) Job security } \\
\text { (3) Time for family } \\
\text { (4) Job transferability } \\
\text { (5) Shape future } \\
\text { (6) Enhance social equity } \\
\text { (7) Make social contribution } \\
\text { (8) Work with children/adolescents } \\
\text { (9) Perceived ability } \\
\text { (10) Prior teaching and learning } \\
\text { (11) Social influence } \\
\text { (12) Fallback career } \\
\text { (13) Expert career } \\
\text { (14) High demand } \\
\text { (15) Social status } \\
\text { (16) Salary } \\
\text { (17) Social dissuasion } \\
\text { (18) Satisfaction with choice }\end{array}$ \\
\hline 9 & $\begin{array}{l}\text { Motivatie om docent } \\
\text { te worden } \\
\text { [Motivation to } \\
\text { become a teacher] [15] }\end{array}$ & $\begin{array}{l}\text { Retrospective by teachers in } \\
\text { function, question with } \\
\text { open end, initially encoded } \\
\text { with } 18 \text { first-order } \\
\text { constructs of FIT-Choice } \\
\text { scale }\end{array}$ & $\begin{array}{l}\text { 21-factor model }(N=1177 \\
\text { teachers })\end{array}$ & $\begin{array}{l}\text { Factors } 1-18 \text { of study } 8 \\
\text { (19) Care for the discipline } \\
\text { (20) Transfer knowledge and skills } \\
\text { (21) Not encodable }\end{array}$ \\
\hline
\end{tabular}


TABLe 1: Continued.

\begin{tabular}{|c|c|c|c|c|}
\hline & Scale & Scale construction & Quantitative factor analysis & Factors \\
\hline 10 & $\begin{array}{l}\text { Reasons for Teaching } \\
\text { Scale (RTS) [22] }\end{array}$ & $\begin{array}{l}\text { Student teachers' motivation } \\
\text { to become a secondary } \\
\text { school teacher [13] }\end{array}$ & $\begin{array}{l}\text { 6-factor model ( } N=215 \\
\text { students) }\end{array}$ & $\begin{array}{l}\text { (1) Intrinsic value } \\
\text { (2) Job benefits } \\
\text { (3) Meaningful relationships } \\
\text { (4) Altruistic views } \\
\text { (5) Ability } \\
\text { (6) Opportunities }\end{array}$ \\
\hline
\end{tabular}

Of the initial 148 items, 56 items were retained by the experts. The items were arranged in random order rather than per category. All items were to be answered by means of a five-point Likert scale, with response categories ranging from 1 (not important), 2 (of little importance), 3 (somewhat important), 4 (important), and 5 (very important).

3.2. Phase 2. During academic year 2012-2013, a cohort of 145 student teachers from one Flemish university completed the questionnaire of 56 items. The questionnaire was administered at the beginning of the teacher education programme. The questionnaire's underlying constructs were subsequently identified by means of exploratory factor analysis.

3.3. Phase 3. Based on the results of the exploratory factor analysis, the questionnaire was shortened to 36 items and administered to a broader sample of student teachers during academic year 2013-2014. Five universities offer a teacher education programme in Flanders. Student teachers $(N=$ 707) from all five universities completed the questionnaire at the start of the academic year. Confirmatory factor analysis was carried out in order to confirm the factor structure produced by the exploratory factor analysis. Multigroup invariance testing is used to determine whether the items are functioning equally for men and women.

\section{Results}

4.1. Exploratory Factor Analysis. Exploratory factor analysis was conducted using SPSS Statistics 20. Oblique rotation was applied during principal factor analysis because of the expected coherence between factors. The discriminant $\left(8.49 \mathrm{E}^{-016}\right)$, Kaiser-Meyer-Olkin measure (.69), and Bartlett's test of sphericity $\left(\chi^{2}(1540)=3799.90, p<.001\right)$ verified that the data were adequate to conduct factor analysis. Based on the screen plot, we compared solutions with $3,6,7$, 8 , and 9 factors. Nonsignificant $(<.40)$ loading items were deleted. Cross-loading items were removed if the differences between the factor loadings were smaller than .20. On the basis of content and statistical arguments, the following 7factor solution (47.26\% explained variance) was obtained:

(i) factor 1: Subject Orientation (7 items; $16.62 \%$ explained variance; $\alpha=.86$ ),

(ii) factor 2: Job Conditions (4 items; 7.71\% explained variance; $\alpha=.74$ ), (iii) factor 3: Job Dynamics (5 items; 6.94\% explained variance; $\alpha=.68)$,

(iv) factor 4: Teaching Orientation (5 items; $4.83 \%$ explained variance; $\alpha=.71$ ),

(v) factor 5: Pupil Orientation (6 items; 4.28\% explained variance; $\alpha=.78$ ),

(vi) factor 6: Idealism (5 items; 3.55\% explained variance; $\alpha=.80)$.

(vii) factor 7: Combining Possibilities (4 items; 3.34\% explained variance; $\alpha=.69$ ).

All factors showed a good to very good internal consistency $(\alpha)$ and made sense in terms of content.

(i) Items loading on factor 1 focus on the discipline or subject the student teacher is going to teach. In particular, the items refer to student teachers' motives for stimulating pupils' interest in and motivation for that discipline.

(ii) Items loading on factor 2 include student teachers' motives for a secure job. Moreover, the teacher's job is considered a logical choice for the student teacher, who do not see other job opportunities.

(iii) Items loading on factor 3 focus on student teachers' motives for the teacher's job because it is an active, dynamic, and varied job, with a lot of autonomy.

(iv) Items loading on factor 4 refer to the joy of teaching, talking in front of an audience, and taking the lead of a group of pupils.

(v) Items loading on factor 5 focus on helping and offering opportunities for every pupil.

(vi) Items loading on factor 6 reflect student teachers' idealism, for example, contributing to society, shaping the next generation, and improving the world by means of teaching. They strive to make society, including education, better.

(vii) Items loading on factor 7 refer to student teachers' motives for combining the teacher's job with other activities (nice working hours, family life, close to home, and a lot of holidays).

These seven factors are listed in Table 2 alongside their constituting items and factor loadings. 
TABLE 2: Items and factor loadings based on the pattern matrix of the 7-factor model.

\begin{tabular}{|c|c|c|}
\hline Factor & Loadings & Items \\
\hline \multirow{7}{*}{ Subject Orientation } & .75 & I would like to motivate pupils about my discipline \\
\hline & .74 & I want to encourage pupils to deepen their understanding of my discipline \\
\hline & .73 & I want to make my discipline more fascinating \\
\hline & .65 & I want to stimulate care for my discipline \\
\hline & .61 & I want to help pupils understand my discipline \\
\hline & .48 & I want to teach pupils something new \\
\hline & .48 & I want pupils to experience pleasure in learning \\
\hline \multirow{4}{*}{ Job Conditions } & .78 & I want a job in education because it provides job security \\
\hline & .63 & The chances of finding a job in education are high \\
\hline & .59 & I see no other job opportunities for me \\
\hline & .57 & Teaching is a logical consequence of my previous study choices \\
\hline \multirow{5}{*}{ Job Dynamics } & .70 & I want a job with lots of variation \\
\hline & .64 & I want a dynamic job \\
\hline & .53 & I want a lot of autonomy in my job \\
\hline & .47 & I want a job in which I do not have to sit still the whole time \\
\hline & .43 & My job should keep on challenging me \\
\hline \multirow{5}{*}{ Teaching Orientation } & .71 & I like standing in front of an audience \\
\hline & .67 & Teaching suits me \\
\hline & .53 & I enjoy teaching \\
\hline & .49 & I like talking \\
\hline & .46 & I like leading a group of pupils \\
\hline \multirow{6}{*}{ Pupil Orientation } & .67 & I want to help pupils \\
\hline & .58 & I want to prepare pupils for further studies or the job market \\
\hline & .52 & I want to offer opportunities to pupils \\
\hline & .52 & I want to show pupils what they are able to do \\
\hline & .52 & I want to make an extra effort for pupils experiencing learning difficulties \\
\hline & .46 & I want to help pupils with their study or career choice \\
\hline \multirow{5}{*}{ Idealism } & .75 & I want to contribute to society by means of education \\
\hline & .67 & I want to shape the next generation \\
\hline & .64 & I want to improve the world a little \\
\hline & 60 & I want to improve education \\
\hline & .50 & I want to encourage pupils' idealism \\
\hline \multirow{4}{*}{ Combining Possibilities } & .70 & I would like to have nice working hours \\
\hline & .64 & I would like to work close to home \\
\hline & .63 & I would like to combine my job with my family life \\
\hline & .46 & I want a lot of holidays \\
\hline
\end{tabular}

4.2. Confirmatory Factor Analysis. Confirmatory factor analysis was conducted using SPSS AMOS 22. Before starting the confirmatory factor analysis, student teachers with missing items $(N=67)$ were excluded from the data file. First, a separate confirmatory factor analysis was conducted for each of the seven factors (Table 3). Two factors, namely, "Idealism" and "Combining Possibilities," showed an adequate fit. The third factor, "Job Dynamics," had a TLI larger than 1 (i.e., 1.004) but this should not be considered problematic: the literature states that TLI can fall outside of the 0-1 range when the $\mathrm{df}$ (i.e., 5) is larger than the $\chi^{2}$ (i.e., 3.88) without implying an erroneous or just-identified model [23]. Modification indices for the four other factors suggested meaningful additions to the factor structure. With respect to "Subject Orientation," an error correlation was suggested between "I want to teach pupils something new" and "I want pupils to experience pleasure in learning" and between "I want to teach pupils something new" and "I want to encourage pupils to deepen their understanding of my discipline." Allowing for these error correlations improved the factor's model fit. Concerning "Job Conditions," we allowed for the suggested error correlation between "Teaching is a logical consequence of my previous study choices" and "I see no other job opportunities for me," which resulted in a TLI larger than 1 (i.e., 1.011). However, as indicated above, this should not be considered problematic since the df (i.e., 1) is larger than $\chi^{2}$ 
TABLE 3: RMSEA and CFI for each factor separately.

\begin{tabular}{lcccc}
\hline \multirow{2}{*}{ Factor } & \multicolumn{2}{c}{ Original factor } & \multicolumn{2}{c}{ Adjusted factor* } \\
& RMSEA & CFI & RMSEA & CFI \\
\hline Subject Orientation & .09 & .96 & .07 & .98 \\
Job Conditions & .17 & .94 & .00 & 1.00 \\
Job Dynamics & .00 & 1.00 & - & - \\
Teaching Orientation & .11 & .96 & .07 & .99 \\
Pupil Orientation & .10 & .94 & .05 & .99 \\
Idealism & .07 & .99 & - & - \\
Combining Possibilities & .05 & .99 & - & - \\
\hline
\end{tabular}

*Allowing for some error correlations.

(i.e., .03). As regards "Teaching Orientation," we allowed for the suggested error correlation between "I like talking" and "I like standing in front of an audience," which improved the model fit. Finally, with regard to "Pupil Orientation," model fit was improved by allowing for the error correlation between "I want to prepare pupils for further studies or the job market" and "I want to help pupils in their study or career choice."

A new confirmatory factor analysis was then conducted on the basis of the three original factors (Idealism, Combining Possibilities, and Job Dynamics) and the four adjusted factors (Subject Orientation, Job Conditions, Teaching Orientation, and Pupil Orientation). When these factors were combined in one model, we found additional suggestions that would improve the model. The modification indices indicated a correlation in the error terms of "I want to give opportunities to pupils" (Pupil Orientation) and "I want to encourage pupils' idealism" (Idealism). The first of these items appears immediately before the second one in the questionnaire, thus explaining the error correlation. Another error correlation was noted between "I want to teach pupils something new" (Subject Orientation) and "I want to contribute to society by means of education" (Idealism); again, these two items appeared one after the other in the questionnaire. Finally, the item "Teaching is a logical consequence of my previous study choices" was omitted because it cross-loaded on the factors "Job Conditions" and "Teaching Orientation." These adjustments produced a 7-factor model with adequate fit: that is, $\mathrm{RMSEA}=.05, \mathrm{CFI}=.89$, and TLI $=.88$. Bollen [24] suggests a value of less than .08 for RMSEA, while a well-fitting model is considered to produce values above .90 for CFI. Thus, the cut-off values are comfortably met for RMSEA but borderline for CFI. In short, we found that the 7-factor model produced by the exploratory factor analysis was confirmed by the confirmatory factor analysis. Descriptive statistics of the 7-factor model, as confirmed by the confirmatory factor analysis, are shown in Table 4.

Correlations between the factors are included in Table 5 . Several factors correlate significantly positively, that is, "Subject Orientation," "Idealism," "Pupil Orientation," "Teaching Orientation," and "Job Dynamics." However, "Job Conditions" and "Combining Possibilities" do not correlate significantly positively with all other factors. Therefore, a profile of seven scores is required instead of one global score for the questionnaire.
TABlE 4: Descriptive statistics (mean and standard deviation) for each factor.

\begin{tabular}{lcc}
\hline Factor & M & SD \\
\hline Subject Orientation & 4.01 & .58 \\
Job Conditions & 2.68 & .77 \\
Job Dynamics & 3.86 & .56 \\
Teaching Orientation & 3.37 & .70 \\
Pupil Orientation & 3.88 & .56 \\
Idealism & 3.44 & .74 \\
Combining Possibilities & 3.49 & .72 \\
\hline
\end{tabular}

TABLE 5: Correlations between the factors.

\begin{tabular}{lccccccc}
\hline Factor & 1 & 2 & 3 & 4 & 5 & 6 & 7 \\
\hline Subject Orientation & 1 & & & & & & \\
Job Conditions & $.12^{* *}$ & 1 & & & & & \\
Job Dynamics & $.27^{* *}$ & $.11^{* *}$ & 1 & & & & \\
Teaching Orientation & $.29^{* *}$ & .01 & $.34^{* *}$ & 1 & & & \\
Pupil Orientation & $.55^{* *}$ & $.10^{*}$ & $.35^{* *}$ & $.36^{* *}$ & 1 & & \\
Idealism & $.45^{* *}$ & $.13^{* *}$ & $.19^{* *}$ & $.33^{* *}$ & $.53^{* *}$ & 1 & \\
Combining Possibilities & -.03 & $.19^{* *}$ & $.21^{* *}$ & .05 & -.01 & -.041 & 1 \\
\hline
\end{tabular}

${ }^{*} p<.05,{ }^{* *} p<.01$.

4.3. Multigroup Invariance Testing. Following the procedure for multigroup invariance testing in AMOS as detailed on by Byrne [25], results indicate invariance of the questionnaire for men and women. From the unconstrained configural model to the model in which factor loadings are held equal for both groups, the $\mathrm{Chi}^{2}$-difference test is not significant $\left(\Delta \chi^{2}\right.$ $=30,042, \Delta d f=28, p=.36$ ). Moreover, the CFI does not worsen from the configural model to the measurement model $(\mathrm{CFI}=.88)$. As such, it is concluded that the items are functioning equally for men and women.

\section{Discussion and Conclusion}

Increasing teacher shortages provide incentives for conducting research into the motives of future teachers aspiring to work in education. The present study builds on previous research measuring motivation for entering the teaching profession, which mainly consists of survey studies using a wide variety of factor solutions. These studies' use of very different methods and techniques for measuring motivation for entering the teaching profession is seen as an important reason for this variety. Here, we introduce three methodological criteria for defining a robust methodology: an empirical foundation, multiphase factor analysis, and large respondent group. An assessment of existing studies based on these three methodological criteria revealed significant differences in the quality of methodology. The aim of this study was therefore to develop a questionnaire measuring motivation to teach while also meeting the three methodological criteria.

Approximately 1200 students were questioned about their motivation at the beginning of their academic teacher education, providing a sound empirical foundation for the questionnaire. Exploratory and confirmatory factor analyses 
were conducted on data from questionnaires completed by 707 student teachers from five universities. The result was a 7-factor model and a 35-item questionnaire, the MMTP (Motives of Masters for the Teaching Profession).

We made every effort to employ a robust methodology in developing the questionnaire. Although we have good reasons to claim that we were successful in doing so, such as the study's empirical foundation, the use of multiphase factor analysis, and the large respondent group, the definition of what constitutes a robust methodology remains open for discussion. It could be argued that a somewhat neglected criterion is generalizability. Empirical research is by its nature context-related and, consequently, may not be generalizable to other contexts. We restricted our research to a certain target group within a specific context, namely, students beginning academic teacher education in Flanders. We attempted to capture the complete picture by addressing the full cohort of these students at the beginning of academic year 2013. Within the region of Flanders, all five universities participated in the study. The reason we limited the study to this specific region is that it has its own educational system and policy. Systemic and political discussions were in fact the reason for initiating the study.

Nevertheless, questions remain about whether the 7factor model and questionnaire can be used in other contexts. From an empirical perspective, contextual differences may manifest as different items, leading to different factors. In fact, the divergence between factor models in previous studies might even be due to contextual differences rather than methodological issues. The study of Watt et al. [26] is an example of an attempt to improve the generalizability of a questionnaire (i.e., FIT-Choice scale) so that it may be used beyond its original context (Australia) in other countries (USA, Germany, and Norway). It is likely that different educational systems and policies lead to different motives for becoming a teacher. The authors' strategy in the study mentioned above, however, was to delete any items that did not apply in all contexts. As a result, context-specific motives were excluded. In our opinion, this strategy weakens the questionnaire. In future cross-contextual research on the MMTP, our preferred strategy would be to add items that have empirical value in at least one context. This way, results from "local" cross-contextual questionnaires would have fewer blind spots.

In any case, caution is warranted when using the MMTP for other types of teachers or in contexts other than that for which it was constructed. Due to the system and policy dependency of research on motivation for education, this consideration may also apply to other questionnaires constructed within a specific educational context. We would advise researchers to state clearly which types of teachers and which contexts were used when constructing items.

The model fit of our final model came close to the cutoffs suggested by Bollen [24]. However, there has been much debate in the literature on the use of golden rules for these fit indexes. Even the frequently cited article by $\mathrm{Hu}$ and Bentler [27] recognized that fit indexes may vary from condition to condition. As a result, we are convinced that a fit close to the suggested cut-off is acceptable for the first validation.
Nonetheless, the current factor structure would benefit from revalidation in future research.

\section{Conflict of Interests}

The authors declare that there is no conflict of interests regarding the publication of this paper.

\section{References}

[1] OECD, Teachers Matter: Attracting, Developing and Retaining Effective Teachers, Organization for Economic Cooperation and Development, Paris, France, 2005.

[2] H. M. G. Watt and P. W. Richardson, "Motivations, perceptions, and aspirations concerning teaching as a career for different types of beginning teachers," Learning and Instruction, vol. 18, no. 5, pp. 408-428, 2008.

[3] P. C. Meijer, G. de Graaf, and J. Meirink, "Key experiences in student teachers' development," Teachers and Teaching: Theory and Practice, vol. 17, no. 1, pp. 115-129, 2011.

[4] I. Rots, A. Aelterman, P. Vlerick, and K. Vermeulen, "Teacher education, graduates' teaching commitment and entrance into the teaching profession," Teaching and Teacher Education, vol. 23, no. 5, pp. 543-556, 2007.

[5] M. Bruinsma and E. P. W. A. Jansen, "Is the motivation to become a teacher related to pre-service teachers' intentions to remain in the profession?" European Journal of Teacher Education, vol. 33, no. 2, pp. 185-200, 2010.

[6] I. Rots, A. Aelterman, G. Devos, and P. Vlerick, "Teacher education and the choice to enter the teaching profession: a prospective study," Teaching and Teacher Education, vol. 26, no. 8, pp. 1619-1629, 2010.

[7] K. Struyven, S. Vrancken, K. Brepoels, N. Engels, and K. Lombaerts, "Being a teacher? Thanks, but no thanks. An investigation into the motives for teachers in Flanders not being willing to start or continue teaching, five years after graduation," Pedagogische Studiën, vol. 89, no. 1, pp. 3-19, 2012.

[8] I. Rots, G. Kelchtermans, and A. Aelterman, "Learning (not) to become a teacher: a qualitative analysis of the job entrance issue," Teaching and Teacher Education, vol. 28, no. 1, pp. 1-10, 2012.

[9] T. Bastick, "Why teacher trainees choose the teaching profession: comparing trainees in metropolitan and developing countries," International Review of Education, vol. 46, no. 3-4, pp. 343-349, 2000.

[10] B. C. S. Yong, “Teacher trainees' motives for entering into a teaching career in Brunei Darussalam," Teaching and Teacher Education, vol. 11, no. 3, pp. 275-280, 1995.

[11] B. J. Young, "Career plans and work perceptions of preservice teachers," Teaching and Teacher Education, vol. 11, no. 3, pp. 281292, 1995.

[12] C. Sinclair, M. Dowson, and D. M. McInerney, "Motivations to teach: psychometric perspectives across the first semester of teacher education," Teachers College Record, vol. 108, no. 6, pp. 1132-1154, 2006

[13] C. Kyriacou, A. Hultgren, and P. Stephens, "Student teachers' motivation to become a secondary school teacher in England and Norway," Teacher Development, vol. 3, no. 3, pp. 373-381, 1999.

[14] H. M. G. Watt and P. W. Richardson, "Motivational factors influencing teaching as a career choice: development and validation of the FIT-choice scale," Journal of Experimental Education, vol. 75, no. 3, pp. 167-202, 2007. 
[15] M. Fokkens-Bruinsma and E. Canrinus, "Wat motiveerde je om docent te worden? Relaties met professionele betrokkenheid en vertrouwen in eigen kunnen bij beginnende en ervaren docenten in het voortgezet onderwijs," Pedagogische StudiënTijdschrift voor Onderwijskunde en Opvoedkunde, vol. 88, no. 1, pp. 41-56, 2010.

[16] P. Smet, Mensen doen schitteren. Eerste Oriëntatienota Hervorming Secundair Onderwijs, Vlaams Ministerie van Onderwijs en Vorming, Brussels, Belgium, 2010.

[17] Vlaams Ministerie van Onderwijs en Vorming, Arbeidsmarktrapport 2011. Basisonderwijs en Secundair Onderwijs, Vlaams Ministerie van Onderwijs en Vorming, Brussels, Belgium, 2011.

[18] A. L. Kalleberg, "Work values and job rewards: a theory of job satisfaction," Social Science Research, vol. 3, pp. 299-322, 1977.

[19] C. Papanastasiou and E. Papanastasiou, "What influences students to choose the elementary education major: the case of Cyprus," Mediterranean Journal of Educational Studies, vol. 3, no. 1, pp. 35-45, 1998.

[20] P. W. Richardson and H. M. G. Watt, "I've decided to become a teacher': influences on career change," Teaching and Teacher Education, vol. 21, no. 5, pp. 457-489, 2005.

[21] C. M. Ferrell and L. G. Daniel, "Construct validation of an instrument measuring teacher career motivations," in Proceedings of the Annual Meeting of the Mid-South Educational Research Association, New Orleans, La, USA, 1993.

[22] M. M. Thomson, J. E. Turner, and J. L. Nietfeld, "A typological approach to investigate the teaching career decision: motivations and beliefs about teaching of prospective teacher candidates," Teaching and Teacher Education, vol. 28, no. 3, pp. 324-335, 2012.

[23] K. K. de Roche, The functioning of global fit statistics in latent growth curve modeling [Doctor of Philosophy dissertation], University of Northern Colorado, 2009.

[24] K. Bollen, Structural Equations with Latent Variables, Wiley, New York, NY, USA, 1989.

[25] B. M. Byrne, Structural Equation Modeling with AMOS, Routledge, New York, NY, USA, 2010.

[26] H. M. G. Watt, P. W. Richardson, U. Klusmann et al., "Motivations for choosing teaching as a career: an international comparison using the FIT-Choice scale," Teaching and Teacher Education, vol. 28, no. 6, pp. 791-805, 2012.

[27] L.-T. Hu and P. M. Bentler, "Cutoff criteria for fit indexes in covariance structure analysis: conventional criteria versus new alternatives," Structural Equation Modeling, vol. 6, no. 1, pp. 1$55,1999$. 

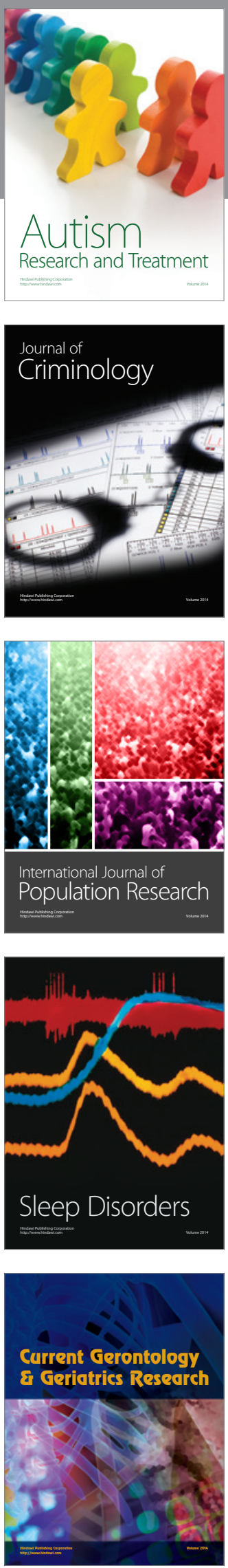
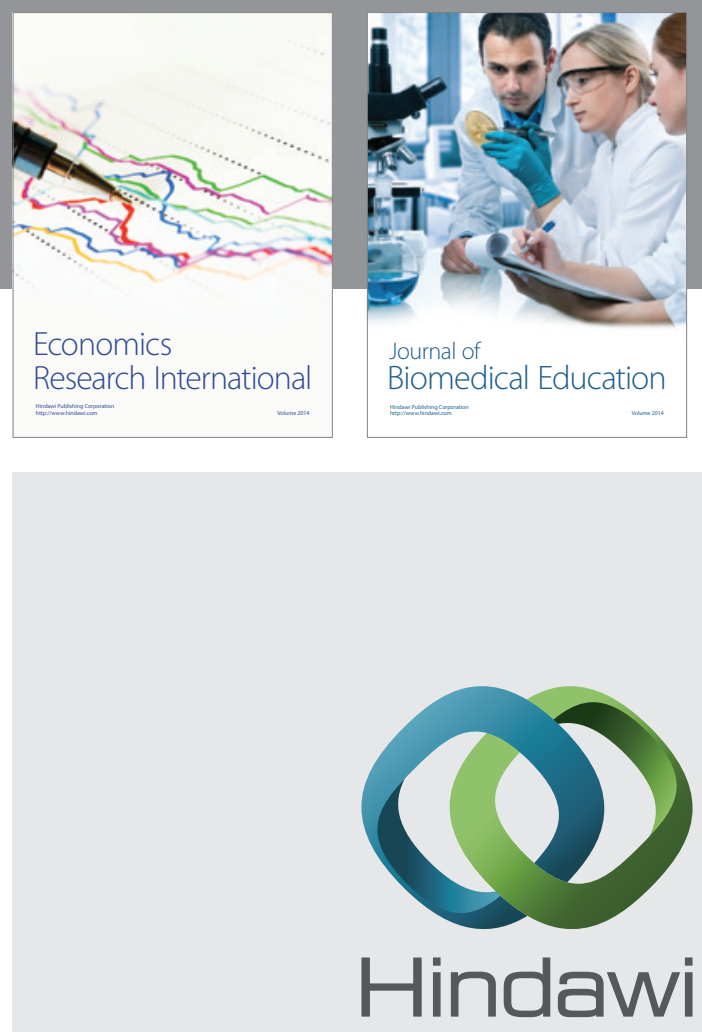

Submit your manuscripts at

http://www.hindawi.com
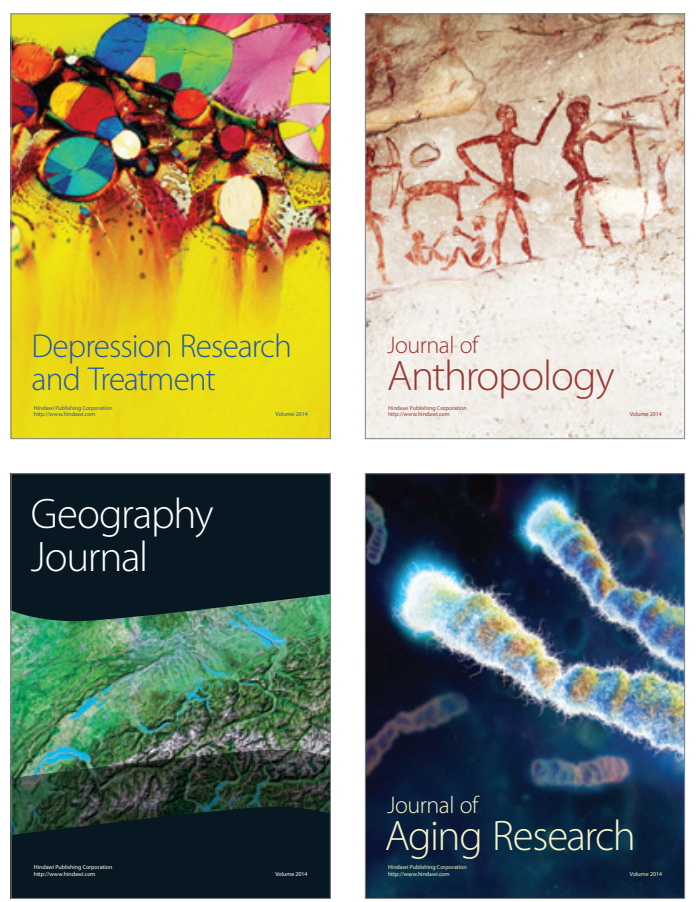
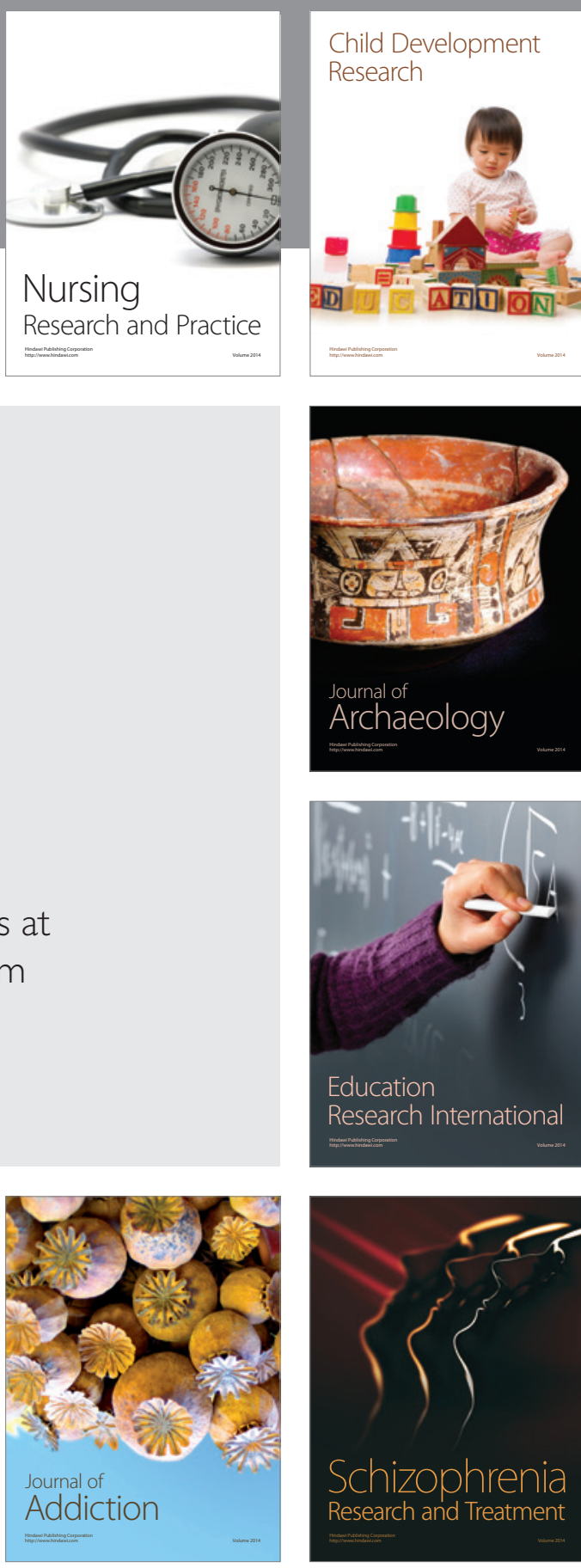

(D)
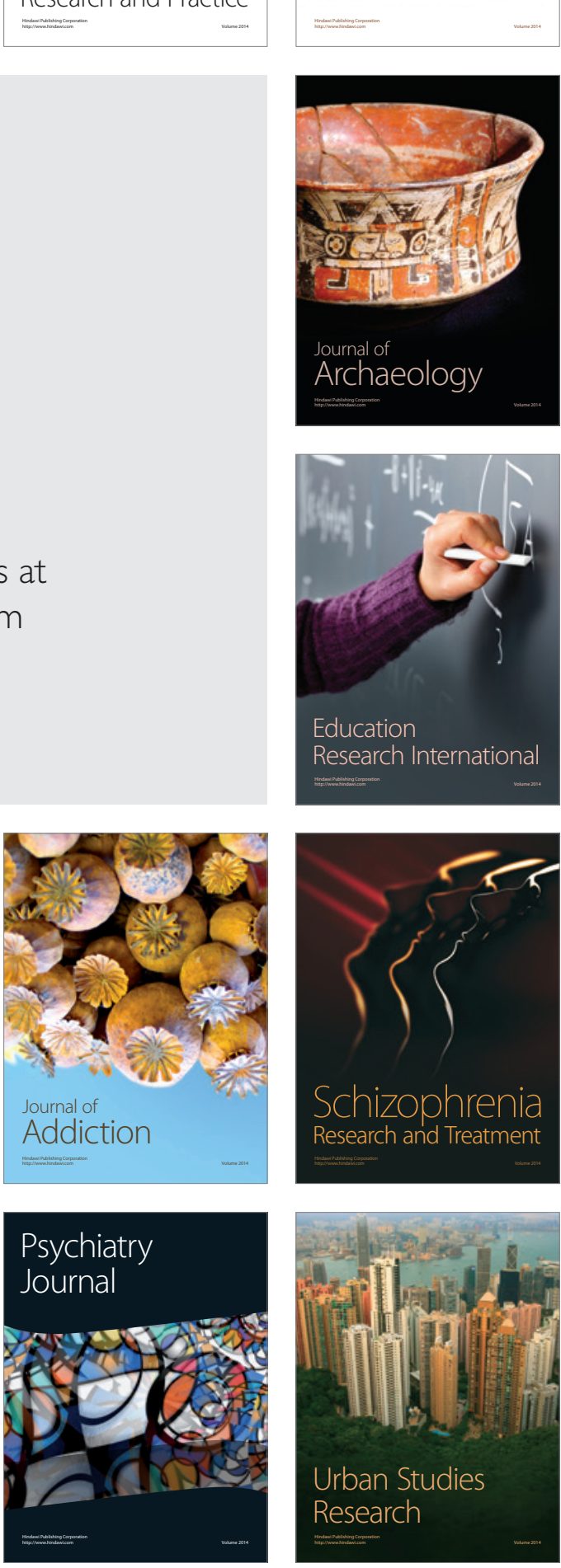